\title{
FAKTOR-FAKTOR YANG BERHUBUNGAN DENGAN PEMAKAIAN KONDOM PADA WANITA PEKERJA SEKSUAL (WPS) DI WILAYAH KERJA PUSKESMAS BANDARBARU KECAMATAN SIBOLANGIT TAHUN 2020
}

\author{
Factors Related To The Condom Use In Sexual Working Women (WPS) In Bandar Baru Public \\ Health Centre Area Of Sibolangit Sub-District In 2020 \\ Dewi Rismauli Bancin, Surya Anita*, Juneris Aritonang \\ Universitas Sari Mutiara Indonesia \\ (surya.anita79@yahoo.co.id, no.telepon/081362312301)
}

\begin{abstract}
ABSTRAK
Salah satu diantaranya adalah upaya menurunkan insiden penyebaran IMS, HIV/AIDS dari pelanggan ke WPS dan sebaliknya. Perilaku menggunakan kondom 100\% atau konsistensi menggunakan kondom pada setiap hubungan seksual seharusnya dilaksanakan termasuk antara WPS dengan pelanggannya. Penelitian ini merupakan penelitian survey dengan menggunakan desain cross sectional yang bertujuan untuk menganalisa berbagai faktor yang berhubungan dengan pemakaian kondom dan teridentifikasinya pemakaian kondom pada WPS. Penelitian ini dilaksanakan di Wilayah Kerja Puskesmas Bandar Baru. Sampel dalam penelitian ini yaitu penghuni WPS yang ada di wilayah kerja Puskesmas Bandar Baru yaitu 84 orang. Hasil penelitian tentang pemakaian kondom oleh WPS, hasil penelitian variabel yang berhubungan dengan pemakaian kondom adalah variabel cara negosiasi dengan nilai OR $=4,455$ artinya WPS yang memiliki cara negoisasai tidak baik mempunyai peluang 4,4 kali lebih berisiko tidak memakaian kondom dibanding WPS yang memiliki cara negoisasai yang baik. Dengan diketahuinya bahwa variabel yang berhubungan terhadap pemakaian kondom oleh WPS di Bandar Baru adalah cara negosiasi maka variabel tersebut penting dirubah ke arah yang positif sehingga menjadikan perilaku yang benar yaitu menggunakan kondom setiap melakukan hubungan seks untuk pencegahan penyakit menular seksual dan HIV/AIDS.
\end{abstract}

\section{Kata kunci: Faktor-faktor, Pemakaian Kondom, WPS}

\begin{abstract}
One of them is an effort to reduce the incidence of Infections Sex Transmited, HIV / AIDS from customers to WPS and vice. The behavior of using 100\% condoms or the consistency of using condoms on every sexual relationship should be carried out including WPS and their customers. This study is a survey study using a cross sectional design that aims to analyze various factors related to condom use and identification of condom use in WPS. This research was carried out in the Bandar Baru community health. The sample in this study were WPS residents in the working area of the Bandar Baru community health, 84 people. The results of research on the use of condoms by WPS, the results of research variables related to condom use is the negotiation variable with an OR $=4.455$ meaning that WPS who have a negative state have a good chance of having 4.4 times more risk of not using a condom than a WPS who has a negative way the good one. By knowing that the variables related to the use of condoms by WPS in Bandar Baru is a way of negotiation, it is important to change these variables in a positive direction so as to make the correct behavior that is using condoms every time they have sex to prevent sexually transmitted diseases and HIV / AIDS.
\end{abstract}

Keywords : Factors, Condom Use, WPS 


\section{PENDAHULUAN}

Pandemi Acquired Immune Deficiency Syndrome (AIDS), sekarang ini dianggap sebagai pandemik paling hebat yang pernah terjadi dalam dua dekade terakhir. AIDS merupakan kumpulan gejala penyakit yang disebabkan Human Immunodeficiency Virus (HIV) yang merusak sistem kekebalan tubuh manusia sehingga daya tahan tubuh makin melemah dan mudah terjangkit penyakit infeksi (Kemenkes, 2012).

Menurut Surveilans Terpadu Biologis dan Perilaku (STBP) Tahun 2011 pada kelompok beresiko tinggi di Indonesia, penggunaan kondom oleh pelanggan WPSL masih sangat rendah. Hal ini terlihat dari jumlah wanita pekerja seks langsung (WPSL) yang pelanggannya menggunakan kondom pada saat hubungan seks terakhir sebesar 69,4\%, sedangkan ketika melihat konsistensinya dalam seminggu hanya 30,6\% WPSL yang pelanggannya selalu menggunakan kondom (Kemenkes, 2012)

Salah satu wilayah yang kasus HIV/AIDS nya tinggi di Sumatera Utara adalah Kabupaten Deli Serdang. Dimana prevalensi HIV/AIDS Deli Serdang berada pada posisi kedua setelah Kota Medan, yaitu sebanyak 169 jiwa ODHA dan 114 jiwa dengan HIV
(+). Penderita penyakit ini lebih dominan pada jenis kelamin laki-laki, yaitu sebanyak 642 jiwa dengan HIV (+) dan 947 jiwa ODHA. Bandar Baru memiliki peringkat nomor lima setelah Bandar Kalifah untuk data kasus KHIV/AIDS, dimana pada Bandar Baru terdeteksi adanya 9 orang terkena HIV dan 2 orang yang positif AIDS (Sumatera Utara, 2017). Tujuan dari penelitian ini adalah Menganalisa berbagai faktor yang berhubungan dalam pemakaian kondom pada WPS di wilayah kerja Puskesmas Bandar Baru Tahun 2020.

\section{METODE}

Jenis penelitian ini adalah survey analitik. Penelitian ini merupakan penelitian survey dengan menggunakan desain cross sectional yang bertujuan untuk menganalisa berbagai faktor yang berhubungan dengan pemakaian kondom dan teridentifikasinya pemakaian kondom pada WPS. Penelitian ini dilaksanakan di Wilayah Kerja Puskesmas Bandar Baru. Sampel dalam penelitian ini yaitu penghuni WPS yang ada di wilayah kerja Puskesmas Bandar Baru yaitu 84 orang. 


\section{HASIL}

\section{A. Analisis Bivariat}

\section{Hubungan Ketersediaan Kondom Dengan Pemakaian Kondom}

Tabel 1. Hubungan Ketersediaan Kondom Dengan Pemakaian Kondom

\begin{tabular}{lcccccccc}
\hline \multirow{2}{*}{$\begin{array}{c}\text { Ketersediaan } \\
\text { Kondom }\end{array}$} & \multicolumn{4}{c}{ Pemakaian Kondom } & \multirow{2}{*}{ Jumlah } & \multirow{2}{*}{$p$} \\
\cline { 2 - 6 } & Pemakai & \multicolumn{2}{c}{ Tidak Pemakai } & & & \\
\hline Tersedia & $\mathrm{n}$ & $\%$ & $\mathrm{n}$ & $\%$ & $\mathrm{n}$ & $\%$ & \\
\hline Tidak tersedia & 21 & 75 & 7 & 25,6 & 17 & 28 & 100 & 0,608 \\
\hline
\end{tabular}

Hasil uji statistik dengan uji Chi-Square menunjukkan tidak ada hubungan yang signifikan antara ketersediaan kondom dengan pemakaian kondom, nilai probabilitas $(\mathrm{p})=0,608>0,05$.

\section{Hubungan Cara Negosiasi Dengan Pemakaian Kondom}

Tabel 2. Hubungan Cara Negosiasi Dengan Pemakaian Kondom

\begin{tabular}{lccccccc}
\hline \multirow{2}{*}{$\begin{array}{l}\text { Cara } \\
\text { Negosiasi }\end{array}$} & \multicolumn{5}{c}{ Pemakaian Kondom } & \multirow{2}{*}{ Jumlah } & \multirow{2}{*}{$p$} \\
\cline { 2 - 7 } & Pemakai & \multicolumn{2}{c}{ Tidak Pemakai } & & & \\
\hline Tersedia & 49 & 80,3 & 12 & 19,7 & 61 & 100 & \\
\hline $\begin{array}{l}\text { Tidak } \\
\text { tersedia }\end{array}$ & 11 & 47,8 & 12 & 52,2 & 23 & 100 & 0,003 \\
\hline Total & 60 & 71,4 & 24 & 28,6 & 84 & 100 & \\
\hline
\end{tabular}

Hasil uji statistik dengan uji Chi-Square menunjukkan adanya hubungan yang signifikan antara cara negosiasi dengan pemakaian kondom, nilai probabilitas $(\mathrm{p})=0,003<0,05$.

\section{Hubungan Karakter Pelanggan Dengan Pemakaian Kondom}

Tabel 3. Hubungan Karakter Pelanggan Dengan Pemakaian Kondom

\begin{tabular}{lccccccc}
\hline \multirow{2}{*}{$\begin{array}{l}\text { Karakter } \\
\text { Pelanggan }\end{array}$} & \multicolumn{9}{c}{ Pemakaian Kondom } & \multirow{2}{*}{ Jumlah } & \multirow{2}{*}{$p$} \\
\cline { 2 - 7 } & \multicolumn{2}{c}{ Pemakai } & \multicolumn{2}{c}{ Tidak Pemakai } & & & \\
\hline & $\mathrm{n}$ & $\%$ & $\mathrm{n}$ & $\%$ & $\mathrm{n}$ & $\%$ & \\
\hline Mendukung & 40 & 75,5 & 13 & 24,5 & 53 & 100 & \\
\hline $\begin{array}{l}\text { Tidak } \\
\text { Mendukung }\end{array}$ & 20 & 64,5 & 11 & 35,5 & 31 & 100 & 0,283 \\
\hline Total & 60 & 71,4 & 24 & 28,6 & 84 & 100 & \\
\hline
\end{tabular}

Hasil uji statistik dengan uji Chi-Square menunjukkan tidak ada hubungan yang signifikan antara karakter pelanggan dengan pemakaian kondom, nilai probabilitas $(\mathrm{p})=0,283>0,05$.

\section{B. Analisis Multivariat}

Tabel 4. Hasil Analisis Multivariat Uji Regresi Logistik Ganda

\begin{tabular}{lcccc}
\hline \multicolumn{1}{c}{ Variabel } & B & Sig. & OR & 95\% CI for $\operatorname{Exp(B)}$ \\
\hline Ketersediaan Kondom & -.567 & .325 & 4.455 & $0.274-2.137$ \\
Cara Negosiasi & 1.568 & .004 & 1.692 & $1.585-12.520$ \\
Karakter pelanggan & .478 & .362 & 0.769 & $0.644-4.446$ \\
Constant & -1.519 & .284 & & \\
\hline
\end{tabular}


Berdasarkan hasil analisis multivariat dengan uji regresi logistik ganda diperoleh hasil bahwa variabel yang berhubungan signifikan terhadap pemakaian kondom yaitu variabel cara negoisasi $(p=0,03)$, sedangkan variabel yang tidak berhubungan yaitu ketersediaan kondom $(\mathrm{p}=0,608)$, dan karakter pelanggan $(\mathrm{p}=0,283)$, (lihat lampiran uji regresi logistik ganda).

Dari ketiga variabel yang berhubungan secara signifikan adalah variabel cara negosiasi dengan $p=0,004$ dengan nilai $\mathrm{OR}=$ 4,455 yang artinya WPS yang memiliki cara negoisasai yang tidak baik mempunyai risiko 4,4 kali lebih berisiko untuk tidak memakai kondom dibandingkan dengan WPS yang memiliki cara negosiasi yang baik.

\section{PEMBAHASAN}

Hasil penelitian dapat diihat bahwa mayoritas responden pemakai kondom saat melakukan hubungan seks dengan pelanggan yaitu 60 orang $(71,4 \%), \quad$ selebihnya dinyatakan tidak pemakai kondom yaitu 24 orang $(28,6 \%)$. Jika dilihat dari jawaban responden maka mayoritas responden menjawab bahwa mereka selalu menganjurkan syarat agar setiap melakukan hubungan seks pelanggan harus menggunakan kondom,

Namun seringkali syarat yang diajukan tidak dipenuhi pelanggan karena keputusan menggunakan jasa WPS tergantung pada pelanggan, jika pelanggan tidak mau dengan syarat tersebut maka pelanggan dapat mencari WPS yang mau melakukan hubungan seks tanpa mengajukan syarat-syarat untuk menggunakan kondom, dan itu berarti WPS akan kehilangan pelanggan (Herlina Dwi Arjianti, 2017).

Dari ketiga variabel yang berhubungan secara signifikan adalah variabel cara negosiasi dengan $p=0,004$ dengan nilai $\mathrm{OR}=$ 4,455 yang artinya WPS yang memiliki cara negoisasai yang tidak baik mempunyai risiko 4,4 kali lebih berisiko untuk tidak memakai kondom dibandingkan dengan WPS yang memiliki cara negosiasi yang baik.

Perilaku adalah unik dan individual. Perilaku seorang dengan orang lain akan berbeda meskipun pada orang dengan kembar identik sekalipun. Perbedaan perilaku tidak selalu disebabkan oleh kondisi yang berurutan artinya perilaku yang positif tidak selalu dipengaruhi oleh hal yang positif, demikian juga sebaliknya (Sianturi, 2013).

Hal ini berarti perilaku sangat dipengaruhi oleh multi variabel. Berdasarkan hasil penelitian menunjukkan bahwa mayoritas perilaku dalam melayani pelanggan tidak menggunakan kondom. Dampak penggunaan kondom yang tidak rutin pada saat melakukan hubungan seksual sangat berisiko terjadi 
penularan HIV/AIDS, terutama bagi profesi WPS(Retnowati \& Purwanti, 2015)

Secara signifikan variabel yang paling dominan mempengaruhi yaitu negosiasi artinya bahwa dengan cara negosiasi yang baik dari WPS kepada pelanggan maka akan menimbulkan keinginan pelanggan menggunakan kondom pada saat melakukan hubungan seksual dengan WPS (Purba et al., 2014).

Bentuk negosisasi yang baik yang diterapkan WPS secara otomatis akan membantu untuk menurunkan angka penyebaran penyakit menular seksual termasuk HIV/AIDS (Soekidjo Notoatmodjo, 2012)

\section{KESIMPULAN}

Negosiasi merupakan faktor yang paling berperan untuk mempengaruhi pelanggan menggunakan kondom saat melakukan hubungan seksual dengan WPS.

Saran dalam penelitian ini kepada petugas kesehatan untuk memberikan pelatihan kepada WPS dalam hal keterampilan negosiasi penggunaan kondom kepada pelanggan.

\section{DAFTAR PUSTAKA}

Herlina Dwi Arjianti, Y. D. P. S. (2017). Konsistensi Penggunaan Kondom Untuk Pencegahan PMS dan HIV Pada Pekerja Seksual. Jurnal of Health Education, 2(2), 146-155. http://jurnal.unnes.ac.id/sju/index.php/jh ealthedu/

Kemenkes. (2012). Survailans Terpadu Biologi dan Perilaku (STBP) pada Kelompok Berisiko Tinggi di Indonesia tahun 2012.

Purba, I. W., Rochadi, R. K., \& Keloko, A. B. (2014). Gambaran Pengetahuan Wanita Pekerja Seks ( Wps ) Tentang Penyakit Hiv / Aids Dilokalisasi Bukit Maraja Desa Marihat Bukit Kecamatan Gunung Malela Kabupaten Simalungun 2014.

Retnowati, M., \& Purwanti, S. (2015). Analisis Faktor yang Mempengaruhi Perilaku Wanita Pekerja Seksual ( WPS ) dalam Menggunakan Kondom untuk Pencegahan HIV / AIDS di Lokalisasi Gang Sadar Baturaden. Jurnal Ilmiah Kebidanan, 6(2), 20-28.

Sianturi. (2013). Hubungan Faktor Predisposisi, Pendukung, Dan Penguat Dengan Tindakan Penggunaan Kondom Pada WPS Untuk Pencegahan HIV / AIDS Di Kabupaten Serdang Bedagai. Jurnal Precure, 1(1), 1-7.

Soekidjo Notoatmodjo. (2012). Promosi Kesehatan dan Ilmu Perilaku.

Sumatera Utara, profil kesehatan. (2017). Profil Kesehatan Sumut 2017. Journal of Chemical Information and Modeling, 53(9),1689-1699.

https://doi.org/10.1017/CBO9781107415 324.004 
